\title{
Effect of plant density and genotype on root size and recovery of Cenourete ${ }^{\circledR}$ raw-material
}

\author{
Milza M Lana; Agnaldo DF Carvalho \\ Embrapa Hortaliças, C. Postal 218, 70351-970 Brasília-DF; milza.lana@embrapa.br; agnaldo.carvalho@embrapa.br
}

\begin{abstract}
Cenourete $^{\circledR}$ is a cut and peeled mini carrot, produced by the abrasion of 55-60 mm cylindrical carrot root segments. The longer and the thinner the carrot root, the higher is the recovery of Cenourete ${ }^{\circledR}$. Two new carrot genotypes obtained at Embrapa Hortaliças, Brasília, Brazil, populations 1012568 (P68) and 1012575 (P75), and the cultivar Esplanada were evaluated in relation to the production of roots for mini carrot manufacture. Two crops were cultivated in the summer of 2010-2011 under the densities 8, 10 and 12 lines/meter in order to obtain respectively $1.06,1.33$ and 1.60 million plants/ha and harvested approximately 3 months after sowing. We evaluated the total root production $(\mathrm{kg} / \mathrm{ha})$, the diameter, the length and the weight of individual roots and the production of root pieces $60 \mathrm{~mm}$ long with diameter in the ranges $<15 \mathrm{~mm}, 15-25 \mathrm{~mm}, 25-30 \mathrm{~mm}$. Total yield of $60 \mathrm{~mm}$ root pieces varied from 19,000 to $34,000 \mathrm{~kg} / \mathrm{ha}$ depending on treatment. Total yield from cv. Esplanada was significantly higher than yield from genotypes P68 and P75 which did not differ from each other. The new genotypes produced longer and thinner roots compared to cv. Esplanada, what resulted in higher production of smaller root pieces (diameter $<15 \mathrm{~mm}$ ) and a corresponding lower proportion of larger pieces (diameter of 25-30 mm). Plant density had no influence on the total production of root pieces but affected the recovery of particular size ranges, with the proportion of smaller pieces increasing at higher density. The amount of cut waste varied from about 3,000 to $7,000 \mathrm{~kg} /$ ha depending on treatment. $\mathrm{Cv}$. Esplanada produced a higher mass of cut waste than P68 and P75 due to a larger amount of pieces with diameter higher than $30 \mathrm{~mm}$. Although increased plant density reduced root size of all genotypes, the variation in root length and root diameter was mainly due to genotype effect.
\end{abstract}

Keywords: Daucus carota, minimal processing, plan density, Cenourete ${ }^{\circledR}$.

\section{RESUMO}

Efeito da densidade de plantio e do genótipo sobre tamanho de raiz e produção de matéria-prima para Cenourete ${ }^{\circledR}$

Cenourete ${ }^{\circledR}$ é uma cenoura minimamente processada obtida pela abrasão de pedaços cilíndricos de cenoura com comprimento de 55-60 $\mathrm{mm}$. Quanto mais longa e fina a raiz de cenoura, maior o rendimento no processamento. Dois novos genótipos de cenoura obtidos na Embrapa Hortaliças, populações 1012568 (P68) e 1012575 (P75), e a cultivar Esplanada foram avaliados visando a produção de matéria-prima para processamento de mini-cenouras do tipo Cenourete ${ }^{\circledR}$. Foram feitos dois plantios no verão de 2010-2011 nas densidades de 8,10 e 12 linhas/m de modo a obter-se respectivamente $1,06,1,33$ e 1,60 milhão plantas/ha e as raízes foram colhidas cerca de três meses após a semeadura. Foram avaliados a produção total de raiz $(\mathrm{kg} / \mathrm{ha})$, o diâmetro, o comprimento e o peso médio de raízes individuais e a produção de matéria-prima $(\mathrm{kg} / \mathrm{ha})$ constituída por pedaços de raiz com $60 \mathrm{~mm}$ de comprimento nas faixas de diâmetro $<15 \mathrm{~mm}, 15-25$ $\mathrm{mm}, 25-30 \mathrm{~mm}$. A produção total de pedaços de $60 \mathrm{~mm}$ variou de 19.000 a $34.000 \mathrm{~kg} / \mathrm{ha}$ dependendo do tratamento. A produção total da cv. Esplanada foi superior à produção dos genótipos P68 e P75 que não diferiram entre si. Os dois novos genótipos produziram raízes mais finas e compridas comparativamente à Esplanada, o que resultou em maior proporção de pedaços menores (diâmetro inferior a $15 \mathrm{~mm}$ ) e correspondente menor produção de pedaços maiores (25-30 mm). O adensamento da cultura não afetou a produção total, mas teve efeito significativo sobre a produção de pedaços em determinadas faixas de diâmetro. A quantidade de refugo na fase de corte das raízes variou de 3.000 a $7.000 \mathrm{~kg} /$ ha dependendo do tratamento. A cv. Esplanada produziu maior massa de pedaços refugo devido à maior proporção de pedaços com diâmetro superior a $30 \mathrm{~mm}$. Apesar do aumento da densidade de plantio ter reduzido significativamente o tamanho das raízes de todos os genótipos, a variação em diâmetro e comprimento das raízes foi em grande parte devida ao genótipo.

Palavras-chave: Daucus carota, processamento mínimo, densidade de plantio, Cenourete ${ }^{\circledR}$.

(Recebido para publicação em 19 de janeiro de 2012; aceito em 7 de maio de 2013)

(Received on January 19, 2012; accepted on May 7, 2013)

$\mathrm{C}$ enourete ${ }^{\circledR}$ is a minimally processed carrot similar to the American 'baby carrot'. Its production consists of polishing cylindrical carrot root segments which are $55-60 \mathrm{~mm}$ long with a diameter equal to or lower than $30 \mathrm{~mm}$. Cenourete $^{\circledR}$ production technology was first developed to add value to thin roots that are left in the field or sold at a lower price, using cv. Alvorada (Lana et al., 2001). The cv. Alvorada belongs to the group of cultivars named Brasília and has uniform orange colour what makes it suitable for processing operations where the roots are peeled and the internal root tissues are exposed. Later on, the introduction of cultivar Esplanada (Vieira et al., 2005), characterized by longer and thinner roots, allowed the cultivation of carrot especially for processing.

Esplanada, like all cultivars from the 'Brasília' group, is well adapted to tropical summer conditions due to its resistance to leaf blight disease. Under climatic conditions like those encountered in the Northeast, Central 
and Southeast regions of Brazil it can be cultivated all over the year if irrigation is provided during the dry season (Vieira et al., 2005). During Brazilian summer time, when imported cultivars without leaf blight resistance cannot be cultivated, Esplanada is the best option for mini carrot production. Under conditions of Brasília winter $\left(15^{\circ} 45^{\prime} \mathrm{S}\right.$, $\left.47^{\circ} 57^{\prime} \mathrm{W}\right)$, the performance of $\mathrm{cv}$. Esplanada was somewhat inferior when compared to hybrids indicated for babycarrot production in the USA. Although the total production of Cenourete ${ }^{\circledR}$ from cv. Esplanada was equivalent or higher than that from the hybrid SugarSnax54, the recovery of Premium (smaller) Cenourete $^{\circledR}$ from Esplanada was lower because under all conditions evaluated its roots were shorter and thicker than SugarSnax 54 roots (Lana, 2012).

Additional selection cycles on the same population that originated cv. Esplanada resulted in two new genotypes for mini carrot production with longer and thinner roots. These results were obtained in planting systems indicated for fresh market carrots, which are conditions that favour the radial growth of the roots. It is well known that carrot root size is highly dependent on cultural conditions (Salter et al., 1979; Salter et al., 1980; Lazcano et al., 1998; Rajasekaran et al., 2006), then it is expected that the performance of these new genotypes as raw material for mini carrot production can be improved through adjustments in the production system.

Previous studies with cv. Esplanada showed that anticipating harvest and increasing plant density enhanced the recovery of premium Cenourete ${ }^{\circledR}$ (Lana, 2012; Silva et al., 2008b). Although it did not affect total yield, increasing plant population to around 1.000 .000 plants/ha and harvesting between 80 and 90 days after sowing (d.a.s) was important to assure that a larger proportion of thinner roots were produced and consequently the production of superior quality Cenouretes $^{\circledR}$ was higher. It is expected that the same holds true for the new genotypes described above. It is also possible that even denser crop systems can be used. In previous experiments, increasing cv. Esplanada plant density from 6 to 10 lines/meter (equivalent to a population of 600.000 to $1.000 .000 \mathrm{pl} /$ ha) showed no evidence that competition limit was achieved since there was no decrease in production at the densest treatment (Lana, 2012).

In the present study the performance of the two new genotypes and of cv. Esplanada are compared in order to evaluate the effect of line spacing on root yield, root size and recovery of Cenourete $^{\circledR}$ raw material.

\section{MATERIAL AND METHODS}

Experiments were carried out at Embrapa Vegetables' Experimental Field, Brasília, Brazil, in the summer of 2010-2011. The combination of three genotypes and three plant densities was evaluated in a randomized block design with 5 replicates. The genotypes grown were cv. Esplanada and two new populations 1012568 and 1012575, named here respectively P68 and P75. The plant densities were obtained by sowing the seeds by hand in transversal lines on a $100 \mathrm{~cm}$ wide bed with wheelings of $50 \mathrm{~cm}$, in order to obtain 8, 10 and 12 lines/meter, what corresponded to a distance of $12.5,10$ and $8.3 \mathrm{~cm}$ between lines, respectively. Each plot was $4 \mathrm{~m}$ long. Thinning was performed 20 d.a.s. leaving 20 plants/meter within each line, so that differences between treatments were solely due to distance between lines. All other cultural practices were done as recommended by Vieira et al. (1997). The experiment was performed twice. The first one was sown in the second week of November 2010 and the second one was sown 40 days later.

Roots were harvested 97 and 90 d.a.s. in Experiments 1 and 2 respectively. All roots were washed and classified into two classes: root waste (split, cracked, lower than $60 \mathrm{~mm}$ long) and processable root. Roots in each class were counted and weighed separately. From each replicate, 50 processable roots were chosen randomly and evaluated individually for length $(\mathrm{cm})$, diameter $(\mathrm{mm})$ at the middle portion of the root and weight (g). Afterwards, all processable roots were pooled and cut into $60 \mathrm{~mm}$ long cylindrical segments using the equipment "Cortadora Horizontal" (Silva et al., 2008a). The root segments were classified into four classes: cut waste (crowns, tips, segments shorter than $60 \mathrm{~mm}$ and/or with wider diameter higher than $30 \mathrm{~mm}$, segments with defects such as green parts, cracking, discolouration and misshape); wider diameter lower than $15 \mathrm{~mm}$; wider diameter between 15-25 mm; wider diameter between 25-30 mm using a template especially developed for it and described in Silva et al. (2008a). Segments in each class were weighed separately using an electronic scale with division of $10 \mathrm{~g}$.

Actual plant density and yield were calculated on an overall basis, i.e., considering the area from mid-wheeling to mid-wheeling.

Analysis of variance for the effect of genotype, experiment and plant density on yield and number of plants was performed using PROC GLM from SAS (SAS Institute 9.1 for Windows). The $\mathrm{R}^{2}$ statistics was calculated according to Hatcher \& Stepanski (1994), and it indicates the proportion of the variance in the criterion variable that is accounted for by the study's predictor variable(s). Values of $\mathrm{R}^{2}$ ranged from 0.00 to 1.00 , with larger values indicating larger treatment effect. Mean separations were analysed by Tukey test at 5\% level. Histograms were obtained by PROC UNIVARIATE in SAS.

\section{RESULTS AND DISCUSSION}

Plant Number - Target plant densities for the treatments 8,10 and 12 lines/meter were respectively $1.06,1.33$ and 1.60 million plants/ha. Achieved population was very close to the target (data not shown). In some plots it was slightly higher indicating that thinning was less intense than needed to assure 20 plants/meter in the line. Because an excess amount of seed was used at sowing, it was possible to achieve the target population despite of the patchy stand obtained as a result of heavy rains during cultivation of both experiments.

The total number of plants was not significantly affected by experiment 
Table 1. Number of processable and waste carrot roots (number of plants/hectare) depending on experiment (1 and 2), genotype (cv. Esplanada-Esp, 1012568-P68, 1012575-P75) and plant density (8,10 and 12 lines/meter) (data are from both experiments) [número de raízes processáveis e refugo (número de plantas/ha) em função do experimento (1 e 2), genótipo (cv. Esplanada-Esp, 1012568-P68, 1012575-P75) e densidade de plantio (8, 10 e 12 linhas/ metro)]. Brasília, Embrapa Hortaliças, 2011.

\begin{tabular}{lll}
\hline & Waste root & Processable root \\
\hline Experiment & & \\
\hline 1 & $337,953 \pm 120,764 \mathrm{~B}$ & $859,542 \pm 147,455 \mathrm{~A}$ \\
2 & $560,405 \pm 170,805 \mathrm{~A}$ & $699,923 \pm 92,363 \mathrm{~B}$ \\
\hline Genotype & & \\
\hline P68 & $484,021 \pm 178,284 \mathrm{~A}$ & $725,801 \pm 120,820 \mathrm{~B}$ \\
P75 & $492,609 \pm 201,967 \mathrm{~A}$ & $713,608 \pm 83,639 \mathrm{~B}$ \\
Esplanada & $375,776 \pm 153,794 \mathrm{~B}$ & $895,329 \pm 149,620 \mathrm{~A}$ \\
\hline Plant density (1/m) & & \\
\hline 8 & $321,792 \pm 116,261 \mathrm{C}$ & $713,617 \pm 83,994 \mathrm{~B}$ \\
10 & $455,053 \pm 162,651 \mathrm{~B}$ & $794,663 \pm 137,952 \mathrm{~A}$ \\
12 & $570,442 \pm 181,103 \mathrm{~A}$ & $826,052 \pm 179,073 \mathrm{~A}$ \\
\hline
\end{tabular}

*Means \pm standard deviation in the same column followed by the same letter are not statistically different by Tukey test at $p=0.05$ (medias \pm desvio padrão na mesma coluna, seguida da mesma letra não difere estatisticamente; Tukey $5 \%$ ); data refer to both experiments, evaluated altogether (os dados se referem aos dois experimentos analisados em conjunto).

Table 2. Single effects of genotype and plant density within each experiment on the production of carrot roots $(\mathrm{kg} / \mathrm{ha}$ ) (efeito isolado de genótipo e densidade de plantio em cada experimento sobre a produção de raízes de cenoura em kg/ha). Brasília, Embrapa Hortaliças, 2011.

\begin{tabular}{|c|c|c|c|}
\hline & Total root & Waste root & Processable root \\
\hline \multicolumn{4}{|l|}{ Genotype } \\
\hline \multicolumn{4}{|c|}{ Experiment 1 (harvested 97 days after sowing) } \\
\hline P68 & $35568 \pm 2678 \mathrm{~B}$ & $1679 \pm 555 \mathrm{AB}$ & $33329 \pm 2854 \mathrm{~B}$ \\
\hline P75 & $39029 \pm 2426 \mathrm{~B}$ & $1360 \pm 405 \mathrm{~B}$ & $34797 \pm 4033 \mathrm{~B}$ \\
\hline Esplanada & $42881 \pm 4218 \mathrm{~A}$ & $1740 \pm 491 \mathrm{~A}$ & $40187 \pm 4033 \mathrm{~A}$ \\
\hline \multicolumn{4}{|c|}{ Experiment 2 (harvested 90 days after sowing) } \\
\hline P68 & $26900 \pm 1616 \mathrm{~B}$ & $5826 \pm 1468 \mathrm{~A}$ & $21075 \pm 2234 \mathrm{~B}$ \\
\hline P75 & $27073 \pm 1372 \mathrm{AB}$ & $5383 \pm 1814 \mathrm{~A}$ & $21690 \pm 2037 \mathrm{~B}$ \\
\hline Esplanada & $28658 \pm 2815 \mathrm{~A}$ & $3953 \pm 1167 \mathrm{~B}$ & $24705 \pm 2651 \mathrm{~A}$ \\
\hline \multicolumn{4}{|c|}{ Plant density } \\
\hline \multicolumn{4}{|c|}{ Experiment 1 (harvested 97 days after sowing) } \\
\hline $81 / \mathrm{m}$ & $37148 \pm 2662 \mathrm{~B}$ & $1198 \pm 280 \mathrm{C}$ & $34454 \pm 3129 \mathrm{~A}$ \\
\hline $10 \mathrm{l} / \mathrm{m}$ & $40612 \pm 3796 \mathrm{~A}$ & $1537 \pm 338 \mathrm{~B}$ & $37043 \pm 4467 \mathrm{~A}$ \\
\hline $12 \mathrm{l} / \mathrm{m}$ & $41690 \pm 3684 \mathrm{~A}$ & $2012 \pm 496 \mathrm{~A}$ & $36807 \pm 4765 \mathrm{~A}$ \\
\hline \multicolumn{4}{|c|}{ Experiment 2 (harvested 90 days after sowing) } \\
\hline $81 / \mathrm{m}$ & $27188 \pm 1529 \mathrm{~A}$ & $4007 \pm 1300 \mathrm{~B}$ & $23180 \pm 2337 \mathrm{~A}$ \\
\hline $10 \mathrm{l} / \mathrm{m}$ & $27930 \pm 2787 \mathrm{~A}$ & $5140 \pm 1504 \mathrm{~A}$ & $22789 \pm 3226 \mathrm{~A}$ \\
\hline $12 \mathrm{l} / \mathrm{m}$ & $27516 \pm 2006 \mathrm{~A}$ & $6014 \pm 1654 \mathrm{~A}$ & $21498 \pm 2594 \mathrm{~A}$ \\
\hline
\end{tabular}

*Means \pm standard deviation in the same column, within each experiment, followed by the same letter are not statistically different by Tukey test at $p=0.05$ (medias \pm desvio padrão na mesma coluna, seguida da mesma letra não difere estatisticamente; Tukey $5 \%$ ).
$(\operatorname{Pr}>\mathrm{F}=0.9647)$ and genotype $(\operatorname{Pr}>\mathrm{F}=0.1986)$, and varied only as a function of plant density $(\mathrm{Pr}>\mathrm{F}<.0001)$ as expected.

Number of processable and waste root was dependent on all main factors (experiment, genotype and plant density) and no interaction was significant. In the second experiment, the number of waste root increased due to a large number of very thin roots with less than $1 \mathrm{~cm}$ average diameter (Table 1). Because there was no difference in total plant number between the two experiments, the lower root growth in the second experiment was due to other reasons than plant competition, the most likely being its lower growth period. Harvest was planned to happen 90 d.a.s., based on previous recommendations for $\mathrm{cv}$. Esplanada (Silva et al., 2008b), but heavy rains at this time, in the first experiment, delayed harvest.

Increasing plant density from 8 to 12 lines/meter increased the number of both processable and waste root (Table 1). However, the increase in waste root was in the order of $77 \%$, while that of processable root was only $16 \%$. The new genotypes produced a higher number of waste root and a correspondent lower number of processable root compared with cv. Esplanada (Table 1). With only three density levels it is not possible to build reliable models, but the results indicate that competition between plants may have become too high at 12 lines/ meter or conversely that at this level of competition the roots should be harvested later than at 90 d.a.s. (Salter et al., 1979).

Root Yield - Total root yield varied from 26,606 to $45,338 \mathrm{~kg} / \mathrm{ha}$ depending on treatment on both experiments. Root yield in the second experiment was about half of that obtained in the first one and the interactions experiment*genotype and experiment*plant density were significant for all three root categories, namely total, processable and waste. The much lower root yield in the second experiment was due to a lower root weight, since no statistical difference in number of plants was observed. Differences in temperature and rainfall (data not shown) were small and do not explain such large differences in yield, 

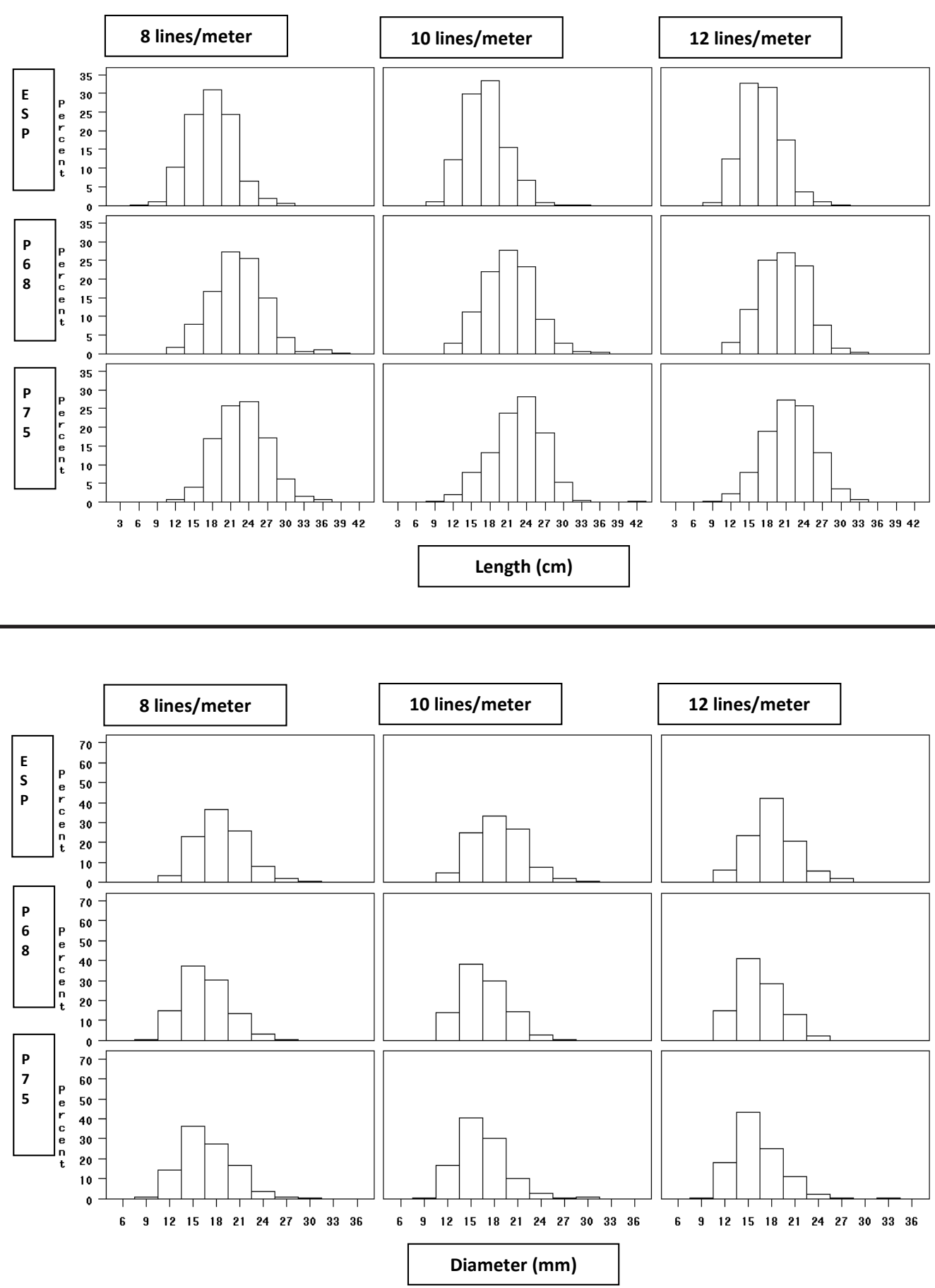

Figure 1. Frequency distribution of individual carrot root length $(\mathrm{cm})$ and root diameter $(\mathrm{mm})$ of genotypes cv. Esplanada (Esp), 1012568 (P68), and 1012575 (P75) at three plant densities (8, 10 and 12 lines/meter). 250 roots per treatment were evaluated in each experiment (frequência de distribuição do comprimento $(\mathrm{cm})$ e do diâmetro $(\mathrm{mm})$ de raiz de cenoura individual dos genótipos cv. Esplanada $($ Esp), 1012568 (P68), e 1012575 (P75) cultivados sob três densidades de plantio (8, 10 e 12 linhas/metro). Foram avaliadas 250 raízes por tratamento em cada experimento). Brasília, Embrapa Hortaliças, 2011.

neither do differences due to soil fertility or disease control. The lower growth period in the second experiment is one of the possible reasons for the lower production although large betweenexperiment effects have been reported by Salter et al. $(1979,1981)$ and ascribed to a number of other reasons.
Fixing the harvest date at 90 d.a.s., based on previous experiments with Esplanada cultivar (Silva et al., 2008b), showed to be a bad strategy since at the 
Table 3. Analysis of variance for the effects of experiment, genotype, plant density and their interactions on the recovery of $60 \mathrm{~mm}$ long carrot root pieces. F values and $\mathrm{R}^{2}$ (the percent of variation that is accounted for by variability in the predictor variable) are shown for the sources of variation (análise de variância para os efeitos de experimento, genótipo, densidade de plantio e suas interações sobre a produção de pedaços de cenoura com $60 \mathrm{~mm}$ de comprimento. Os valores de $\mathrm{F}$ e $\mathrm{R}^{2}$ (a proporção da variância que é explicada pela variável independente) são mostradas para as fontes de variação). Brasília, Embrapa Hortaliças, 2011.

\begin{tabular}{|c|c|c|c|c|c|}
\hline f variation & $<15 \mathbf{m m}^{\mathrm{a}}$ & $15-25 \mathrm{~mm}^{\mathrm{b}}$ & $25-30 \mathrm{~mm}^{\mathrm{c}}$ & Waste $^{\mathrm{d}}$ & Total $^{\mathrm{e}}$ \\
\hline Experiment & $\begin{array}{l}\operatorname{Pr}>\mathrm{F}=<.0001 \\
\mathrm{R}^{2}=0.0509\end{array}$ & $\begin{array}{l}\operatorname{Pr}>F=<.0001 \\
\mathrm{R}^{2}=0.7771\end{array}$ & $\begin{array}{l}\operatorname{Pr}>F=<.0001 \\
\mathrm{R}^{2}=0.5022\end{array}$ & $\begin{array}{l}\operatorname{Pr}>F=<.0001 \\
\mathrm{R}^{2}=0.2986\end{array}$ & $\begin{array}{l}\operatorname{Pr}>F=<.0001 \\
R^{2}=0.7000\end{array}$ \\
\hline Genotype & $\begin{array}{l}\operatorname{Pr}>F=<.0001 \\
\mathrm{R}^{2}=0.6910\end{array}$ & $\begin{array}{l}>\mathrm{F}=<.0001 \\
=0.0881\end{array}$ & $\begin{array}{l}\mathrm{Pr}>\mathrm{F}=<.0001 \\
\mathrm{R}^{2}=0.2622\end{array}$ & $\begin{array}{l}\operatorname{Pr}>\mathrm{F}=<.0001 \\
\mathrm{R}^{2}=0.3445\end{array}$ & $\begin{array}{l}\mathrm{F}=<.0001 \\
.0900\end{array}$ \\
\hline Plant density & , & $\mathrm{Pr}>\mathrm{F}$ & $\begin{array}{l}\operatorname{Pr}> \\
\mathrm{R}^{2}=\end{array}$ & $\begin{array}{l}.0005 \\
7\end{array}$ & $\operatorname{Pr}>F=0.4909$ \\
\hline Experiment* Genotype & $\begin{array}{l}\operatorname{Pr}>\mathrm{F}=<.0001 \\
\mathrm{R}^{2}=0.0689\end{array}$ & $\operatorname{Pr}>\mathrm{F}$ & $\begin{array}{l}\operatorname{Pr}>\mathrm{F}=<.0001 \\
\mathrm{R}^{2}=0.0870\end{array}$ & $\begin{array}{l}\operatorname{Pr}>F=0.0146 \\
R^{2}=0.0274\end{array}$ & $\operatorname{Pr}>F=0.9058$ \\
\hline $\begin{array}{l}\text { Experiment*Plant } \\
\text { density }\end{array}$ & $\begin{array}{l}\operatorname{Pr}>F=0.0251 \\
R^{2}=0.0129\end{array}$ & $\begin{array}{l}\operatorname{Pr}>F=0.0018 \\
\mathrm{R}^{2}=0.0187\end{array}$ & $\operatorname{Pr}>F=0.4024$ & $\begin{array}{l}\operatorname{Pr}>F=0.0142 \\
R^{2}=0.0276\end{array}$ & $\operatorname{Pr}>F=0.0406$ \\
\hline Genotype*Plant density & $\operatorname{Pr}>F=0.3781$ & $\operatorname{Pr}>F=0.3793$ & $\operatorname{Pr}>F=0.6216$ & $\operatorname{Pr}>F=0.3110$ & 0.6246 \\
\hline $\begin{array}{l}\text { Experiment*Genotype* } \\
\text { Plant density }\end{array}$ & $\operatorname{Pr}>F=0.1065$ & $\operatorname{Pr}>F=0.6592$ & $\operatorname{Pr}>F=0.9094$ & $\operatorname{Pr}>F=0.7709$ & $\operatorname{Pr}>F=0.9445$ \\
\hline
\end{tabular}

${ }^{a}$ wider diameter lower than $15 \mathrm{~mm}$; ${ }^{b}$ wider diameter between $15-25 \mathrm{~mm}$; ${ }^{c}$ wider diameter between $25-30 \mathrm{~mm}$; ${ }^{\mathrm{d}}$ crowns, tips, root pieces shorter than $60 \mathrm{~mm}$ and/or with wider diameter higher than $30 \mathrm{~mm}$, segments with defects such as green parts, cracking, discolouration and misshape; 'sum of all above ( ${ }^{\mathrm{a}}$ maior diâmetro inferior a $15 \mathrm{~mm}$; ${ }^{\mathrm{b}}$ maior diâmetro entre $15-25 \mathrm{~mm}$; ${ }^{\mathrm{c}}$ maior diâmetro entre $25-30$ mm; ${ }^{d}$ coroas, pontas, pedaços de raiz menores que $60 \mathrm{~mm}$ e/ou com o maior diâmetro acima de $30 \mathrm{~mm}$, segmentos com defeitos como partes verdes, rachaduras, descoloração e malformações; soma total).

level of competition and/or under the climate conditions experienced in the second experiment the roots needed more time to grow. A better strategy would be one similar to that used by Lazcano et al. (1998) where harvest date was established based on root size from field sampling and the roots were harvested earlier when plant density was lower.

Increasing plant density increased total root yield only in the first experiment and had no effect on processable root yield (Table 2). On both experiments increased plant density resulted in an increase in the production of waste root which varied from 1,231 to $7,192 \mathrm{~kg} / \mathrm{ha}$ and was mainly represented by very thin and small roots.

In general, total and processable root yield from cv. Esplanada was significantly higher than yield from genotypes P68 and P75 which did not differ from each other (Table 2). The amount of root waste from both P68 and P75 was conversely significantly higher compared to cv. Esplanada, and was mainly due to very thin roots (diameter lower than $1 \mathrm{~cm}$ ). These results raise the question whether the new genotypes do need a longer growth period to attain proper size what is object of current investigation.

Root Size - Carrot root size was evaluated in terms of weight, length and diameter. Although an analysis of variance for the effect of treatments was performed, it was chosen to show the frequency distribution of each size attribute instead of the means for each treatment. The histograms (Figure 1) better demonstrate any shift in size that happens as a result of changes in cultivar and plant density. One must take into account that the main objective of adjusting the carrot production system is to increase the proportion of roots that meet a certain size range. Higher industrial yield will be obtained the higher the proportion of roots with diameter equal or lower than $25 \mathrm{~mm}$. Additionally, the length should be as long as possible so that more $60 \mathrm{~mm}$ long root pieces are obtained from each root. Root size variability in carrot crop is substantial and related with plant density (Salter et al., 1981; Gray \& Benjamin, 1993) and again the histogram gives a better visualization of which treatment spans a shorter range of values which would indicate a more homogenous size distribution.

The distribution of root length, combining the data of both experiments, showed a small shift in mean towards higher values for the new genotypes (Figure 1a). Average length was influenced by both genotype $(\mathrm{Fr}>\mathrm{P}=<0001)$ and plant density $(\mathrm{Fr}>\mathrm{P}=<0001) . \mathrm{Cv}$. Esplanada roots were the shortest with $17.3 \mathrm{~cm}$ and P75 the longest with $22.1 \mathrm{~cm}$ on average. Increasing plant length, from 8 to 12 lines/meter, decreased average length significantly of all genotypes by $1.2 \mathrm{~cm}$.

Root mean diameter was influenced by all 3 main factors (experiment, genotype and plant density) independently. Differences among genotypes were larger than differences due to plant density (Figure $1 \mathrm{~b}$ ). $\mathrm{Cv}$. 


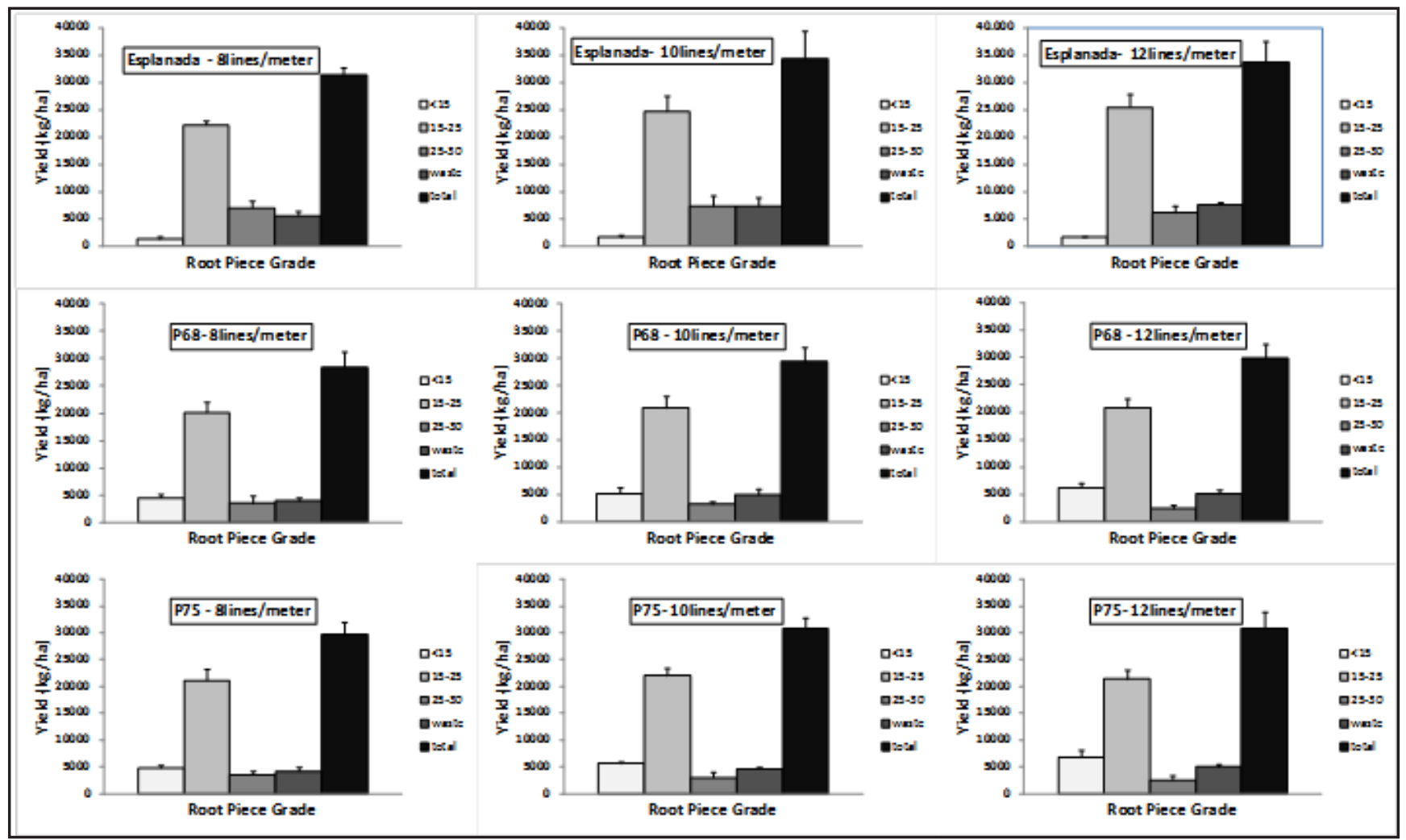

Figure 2. Recovery of 60-m long carrot root pieces from genotypes Esplanada (Esp), 1012568 (P68), and 1012575 (P75) at three plant densities $(8,10$ and 12 lines/meter). Bars are the average of 5 replicates + standard deviation obtained at Experiment 1 (produção de pedaços de cenoura com $6 \mathrm{~cm}$ de comprimento dos genótipos Esplanada (Esp), 1012568 (P68), e 1012575 (P75) cultivados sob três densidades de plantio (8, 10 e 12 linhas/metro). As barras são o valor médio de 5 repetições + desvio padrão obtidos no Experimento 1) Brasília, Embrapa Hortaliças, 2011.

Esplanada was on average $2 \mathrm{~mm}$ larger than the other two genotypes that did not differ from each other. Increasing plant density from 8 lines/meter to 12 lines/meter decreased diameter from an average of 17.3 to $16.8 \mathrm{~mm}$.

Individual root weight (data not shown) was dependent on both experiment $(\mathrm{Fr}>\mathrm{P}=<0001)$ and plant density $(\mathrm{Fr}>\mathrm{P}=<0001)$ but not on genotype $(\operatorname{Pr}>\mathrm{F}=0.1609)$. This indicates that the longer and thinner roots of P75 and P68 had on average the same weight of the thicker and shorter roots of $\mathrm{cv}$. Esplanada.

Although increasing plant density reduced root size of all genotypes significantly, the variation in diameter and length was mainly due to cultivar effect. Analysis of variance for average diameter indicated an $\mathrm{R}^{2}$ value of 0,4505 for cultivar and 0,0244 for plant density. For root length the cultivar effect was even more pronounced and $\mathrm{R}^{2}$ was 0,6826 and 0,0384 respectively for cultivar and plant density.

\section{Yield of $60 \mathrm{~mm}$ root pieces -} Differences in total yield of $60 \mathrm{~mm}$ root pieces due to experiment and genotype effects reflected those observed for root production. Cv. Esplanada was more productive than $\mathrm{P} 68$ and $\mathrm{P} 75$, which did not differ from each other. The lower total yield of the two new genotypes was due to a higher production of pieces in the lower range size $(<15 \mathrm{~mm})$ and a corresponding lower proportion of pieces in the larger range size (25-30 $\mathrm{mm})$. Plant density had no influence on the total production of root pieces but affected the recovery of particular size ranges (Table 3), reflecting differences in root size distribution under different levels of competition (Salter et al., 1979).

On Figure 2 it is presented the yield of root pieces for each genotype*plant density combination. Although the yield in Experiment 2 was about half of that obtained in Experiment 1, resulting in the large effect of Experiment, the proportion of each class was roughly the same on both essays and only data from the first one are presented.

Root pieces in the class $15-25 \mathrm{~mm}$ were predominant in all treatments. On both experiments cv. Esplanada was significantly more productive than the other genotypes which did not differ from each other (Figure 2). Plant density had a marginal effect $(\mathrm{Pr}>\mathrm{F}=0.059)$ that accounted for less than $2 \%$ of the variation in the data set.

The yield obtained from P68 and P75 did not differ in the first experiment but on the second it was significantly higher for P75. The effect of plant density was observed only in the first experiment, where planting with 12 lines/meter resulted in higher recovery of $<15 \mathrm{~mm}$ pieces. In the second experiment, when root growth was reduced, no effect of plant density was observed.

The amount of cut waste varied from about 3,000 to $7,000 \mathrm{~kg} / \mathrm{ha}$ 
depending on treatment. On average, it represented $17 \%$ of the total weight on both experiments, although on absolute numbers it was higher in the first because the roots were larger. On both experiments, cv. Esplanada produced a higher mass of cut waste than P68 and P75 due to a larger amount of pieces with diameter higher than $30 \mathrm{~mm}$. Plant density effect was observed only in the first experiment, when planting with 10 and 12 lines/meter increased the production of waste compared to 8 lines/meter. However in this case, the cut waste was mainly composed of the very thin root tips. This again suggests that the new genotypes may require a longer growth period, especially under high plant densities.

Under the conditions described in the present paper the effect of cultivar was more pronounced than the effect of plant density in the recovery of thinner carrot root pieces for mini carrot production. The total root and total $60 \mathrm{~mm}$ root pieces production from cv. Esplanada was higher than that obtained from the new genotypes P68 and P75. On the other hand, because the new genotypes produced longer and thinner carrot roots, they produced a higher amount of root pieces in the lower range size $(<15 \mathrm{~mm})$ and a corresponding lower proportion of pieces in the larger range size (25-30 $\mathrm{mm}$ ) compared to cv. Esplanada. Plant density had no influence on the total production of root pieces and a marginal effect on the recovery of particular size ranges, where planting with 12 lines/ meter resulted in higher recovery of $<15$ $\mathrm{mm}$ pieces only in the first experiment.

\section{REFERENCES}

GRAY D; BENJAMIN LR. 1993. Controlling the size of carrot - the roles of seed quality and plant density. Acta Horticulturae 354: 47-54.

HATCHER L; STEPANSKI EJ. 1994. A Stepby-Step Approach to Using SAS System for Univariate and Multivariate Statistics. SAS Institute Inc., Gary, N.C. 215 p.

LANA MM;VIEIRA JV; SILVA JBC; LIMA DB. 2001. Cenourete e Catetinho: minicenouras brasileiras. Horticultura Brasileira 19: 376379.

LANA MM. 2012. The effects of line spacing and harvest time on processing yield and root size of carrot for Cenourete ${ }^{\circledR}$ production. Horticultura Brasileira 30: 304-311.

LAZCANO CA; DAINELLO FJ; PIKE LM; MILLER ME; BRANDEBERGER L; BAKER LR. 1998. Seed lines, population density, and root size at harvest affect quality and yield of cut-and-peel baby carrots. HortScience 33: 972-975.

RAJASEKARAN LR; ASTATKIE T; CALDWELL C. 2006. Seeding rate and seed spacing modulate root yield and recovery of slicer and dicer carrots differently. Scientia
Horticulturae 107: 319-324.

SALTER PJ; CURRAH IR; FELLOWS JR. 1979. The effects of plant density, spatial arrangement and time of harvest on yield and root size in carrots. Journal of Agricultural Science 93: 431-440.

SALTER PJ; CURRAH IR; FELLOWS JR. 1980. Further studies on the effects of plant density, spatial arrangement and time of harvest on yield and root size in carrots. Journal of Agricultural Science 94: 465-478.

SALTER PJ; CURRAH IR; FELLOWS JR. 1981. Studies on some sources of variation in carrot root weight. Journal of Agricultural Science 96: 549-556.

SILVA JBC; LANA MM; VIEIRA JV. 2008a. Equipamentos para agroindústria de mini-cenouras Cenourete e Catetinho: 1 . Cortadoras. Brasília: Embrapa Hortaliças, 2008. 14p. (Embrapa Hortaliças. Comunicado Técnico, 60), available at http://www.cnph. embrapa.br/paginas/serie documentos/ publicacoes2008/cot 60.pdf, acessado em 10 jan 2011.

SILVA JBC; VIEIRA JV; LANA MM. 2008b. Processing yield of the carrot cultivar Esplanada as affected by harvest time and planting density. Scientia Horticulturae 115: 218-222.

VIEIRA JV; PESSOA HBSV; MAKISHIMA N.1997. Cultivo da cenoura (Daucus carota L.). Brasília: Embrapa Hortaliças, 1997. 19p. (Embrapa Hortaliças. Instrução Técnica,13).

VIEIRA JV; SILVA JBC; CHARCHAR JM; RESENDE FV; FONSECA MEN; CARVALHO AM; MACHADO CMM. 2005. Esplanada: cultivar de verão para fins de processamento. Horticultura Brasileira 23: 851-52. 